\title{
Characteristics of geopolymer based on recycling resources
}

\author{
Yooteak Kim, Hyunjung $\mathrm{Kim}^{\dagger}$, and Changsub Jang \\ Department of Materials Engineering, Kyonggi University, Suwon 443-760, Korea \\ (Received April 13, 2012)
}

(Revised June 8, 2012)

(Accepted June 11, 2012)

\begin{abstract}
In this study, geopolymer was prepared with reject ash and blast furnace slag using $\mathrm{NaOH}$ as an alkali activator and water glass. The aim of this study was to investigate the compressive strength variation according to the contents of $\mathrm{NaOH}$ and water glass and replacement ratio of reject ash (RA) and blast furnace slag (BS). The compressive strength measured after 28 days was $38.91 \mathrm{MPa}$ for the geopolymer which consist of $100 \%$ of $\mathrm{BS}$ with $1 \mathrm{wt} \% \mathrm{NaOH}$ and $3 \mathrm{wt} \%$ water glass. The major factor for improving compressive strength was the alkali activator proportion and the replacement ratio of RA and $\mathrm{BS}$.
\end{abstract}

Key words Geopolymer, Reject ash, Blast furnace slag, Alkali activator, Water glass, Sodium hydroxide, Compressive strength

\section{재활용 폐자원에 따른 지오폴리머의 특성변화 연구}

\section{김유택, 김현정 ${ }^{\dagger}$ 장창섭}

경기대학교 신소재공학부, 수원, 443-760

(2012년 4월 13일 접수)

(2012년 6월 8일 심사완료)

(2012년 6월 11일 게재확정)

요 약 본 연구는 알칼리 활성화제로 $\mathrm{NaOH}$ 와 물유리를 사용하고 리젝트애쉬와 고로슬래그를 혼합하여 지오폴리머를 제조하였다. 리젝트애쉬와 고로슬래그의 치환율과 물유리와 $\mathrm{NaOH}$ 의 농도에 따른 압축강도를 측정하였다. 압축강도 측정 결과로는 알칼리 활성화제로 $\mathrm{NaOH} 1 \mathrm{wt} \%$, 물유리 $3 \mathrm{wt} \%$ 와 전량 고로슬래그를 사용한 경우 재령 28일차 강도가 38.91 $\mathrm{MPa}$ 의 성능을 나타내었다. 압축강도 증진의 중요한 요인은 알칼리 활성화제의 비율과 리젝트애쉬와 고로슬래그의 치환율 에 의한 것이었다.

\section{1. 서 론}

시멘트를 1 톤 생산하는데 0.4 1.0톤의 $\mathrm{CO}_{2}$ 가스를 배 출하는 등 전 세계 $\mathrm{CO}_{2}$ 가스 배출량의 $7 \%$ 를 차지할 정 도로 심각하다[1]. 이에 많은 연구자들이 친환경을 지향하 는 미래 산업 환경의 변화를 고려하여 이산화탄소의 배출 을 줄이기 위한 노력과 시멘트를 대체할 수 있는 새로운 재료의 개발에 많은 관심을 기울이고 있으며, 최근 몇 년 에 걸쳐 친환경적인 콘크리트에 대한 많은 연구가 이루어 지고 있다[2,3]. 전 세계적으로 풍부하게 입수 가능한 산 업폐기물인 플라이애쉬 및 고로 수쇄 슬래그를 주요 성분

\footnotetext{
Corresponding author

Tel: +82-70-4024-9765

Fax: +82-31-244-6300

E-mail: kimhj@kyonggi.ac.kr
}

으로 이용하여 무기결합재(지오폴리머: Geopolymer) 시멘 트를 제조하는 방법이 활발히 연구되고 있다[4-6].

Geopolymer는 알칼리성 알루미노 실리케이트 시멘트 의 일종으로, 포틀랜드 시멘트와 비교할 때, 낮은 $\mathrm{CO}_{2}$ 방출과 함께 기계적 - 화학적 특성 및 중금속 고정화 특 성이 우수하여 시멘트 대체소재로 기대되고 있다[7-12]. Geopolymer의 구조는 3차원의 망목구조를 가지고 있는 제올라이트와 유사하며 비정질 상이다. Geopolymer의 제조 원료로는 fly ash, metakaolin, blast furnace slag 등의 비정질의 silica 질을 다량함유하고 있는 산업부산물 과 natural silicate mineral 등이 가능하다. Geopolymer는 높은 $\mathrm{pH}$ 하에 알칼리성 금속에 의해서 산업부산물이나 천연광물질로부터 $\mathrm{Si}^{4+}$ 이온과 $\mathrm{Al}^{3+}$ 이온을 용해하고 이 를 축합 중합하는 것으로 합성되며, 일반적인 형태는 $\mathrm{Mn}\left(-\left(\mathrm{SiO}_{2}\right) \mathrm{z}-\mathrm{AlO}_{2}\right) \mathrm{n}, \mathrm{wH}_{2} \mathrm{O}$ 이다. 여기서 $\mathrm{M}$ 은 칼륨, 나 
트륨, 칼슘 등의 알칼리성 원소를 가리키며, $\mathrm{Z}$ 는 1,2 , $3, \mathrm{n}$ 은 축합중합의 정도를 나타낸다[2].

리젝트애쉬는 플라이애시와 함께 화력발전소에서 전기 를 생산하는 과정에서 얻어지는 산업부산물 (by-product) 이다. 현재 폐기물로 지정되어 있으며, 대부분 매립 처리 되고 있어 재활용을 위한 연구가 아직 초기단계에 머물 러 자원화 되지 못하고 있는 실정이다[13]. 또한, 최근에 는 이러한 환경문제로 인하여 시멘트를 전혀 사용하지 않는 시멘트 ZERO 콘크리트 개발에 관한 연구가 주목 을 받고 있다. 무기결합재(Geopoltmer) 시멘트 제조에 사용되는 고로슬래그 미분말은 연간 약 800 만톤 이상으 로 2000년대 초까지도 재활용이 낮아 상당한 양의 재고 가 쌍여 있었으나, 최근 보통포틀랜드 시멘트 생산 시 중량재, 혼합시멘트 및 레미콘 혼화재 등으로 사용량이 급증함에 따라 재활용율이 $100 \%$ 에 근접하게 되었다. 그러나 2010년부터 제철소가 추가로 가동되면서 향후 고로슬래그 미분말의 발생 양은 계속 증가 할 것으로 판 단되므로 이에 대한 대책이 필요하다. 그에 따라 고로슬 래그 미분말, 리젝트애쉬 등 산업부산물을 이용한 알칼 리 활성 모르터에 대해 국내외적으로 다양한 연구가 진 행되어 일부 실용화가 이루어지고 있으나, 아직까지 해 명되지 않은 부분이 많다. 특히 리젝트애쉬와 고로슬래 그 미분말을 혼합 사용한 알칼리 활성화에 대한 연구는 기초단계에 있으며, 알칼리 활성화제, 결합재의 혼합비율 등이 모르터에 미치는 영향에 대한 체계적인 연구가 필 요한 실정이다.

따라서 본 연구에서는 리젝트애쉬와 고로슬래그를 주원료로 사용하여 포틀랜드 시멘트의 대체소재로서 Geopolymer 무기결합재의 활용 가능성을 알아보고자 하 였으며 우수한 특성을 지닌 알칼리 활성화제로 수산화나
트륨과 물유리를 사용하여 첨가량에 따른 Geopolymer 의 미세조직 변화 및 압축강도에 미치는 영향에 대하여 연구하였다.

\section{2. 실험개요}

\section{1. 사용재료}

\subsection{1. 리젝트애쉬(Reject ash)}

석탄 화력발전소에서 석탄을 연소하고 발생되는 애쉬 를 크게 플라이애쉬(Fly ash)와 바텀애쉬(Bottom ash)로 구분하고 플라이애시는 석탄이 보일러에서 연소된 후 전 기집진기에 포집되는 분말상태의 애쉬를 말한다. 플라이 애시는 다시 정제회와 잔사회로 분류되는데 아직 정제하 지 않은 플라이애쉬를 정제공장에서 원심분리방식 등으 로 정제한 애쉬를 정제회라고 하고 이때 하부로 낙하된 탄소함량 $5 \%$ 이상인 애쉬를 리젝트애쉬(Reject ash)라 고 한다.

본 실험에 사용한 리젝트애쉬는 국내 $\mathrm{Y}$ 발전소에서 발생된 폐석탄회로서 그 화학조성은 다음의 Table 1과

Table 1

Chemical compositions of RA and BS

\begin{tabular}{llllllll}
\hline \multicolumn{7}{c}{ Chemical Compositions (wt\%) } \\
\hline Brand & $\mathrm{SiO}_{2}$ & $\mathrm{Al}_{2} \mathrm{O}_{3}$ & $\mathrm{Fe}_{2} \mathrm{O}_{3}$ & $\mathrm{CaO}$ & $\mathrm{MgO}$ & $\mathrm{SO}_{3}$ & Ig. loss \\
\hline RA & 66.06 & 21.05 & 3.28 & 1.24 & 0.56 & 0 & 5.31 \\
BS & 37.12 & 12.84 & 0.19 & 43.13 & 5.38 & 0 & 0 \\
\hline
\end{tabular}

1) RA: Reject Ash.

2) BS: Blast furnace slag.

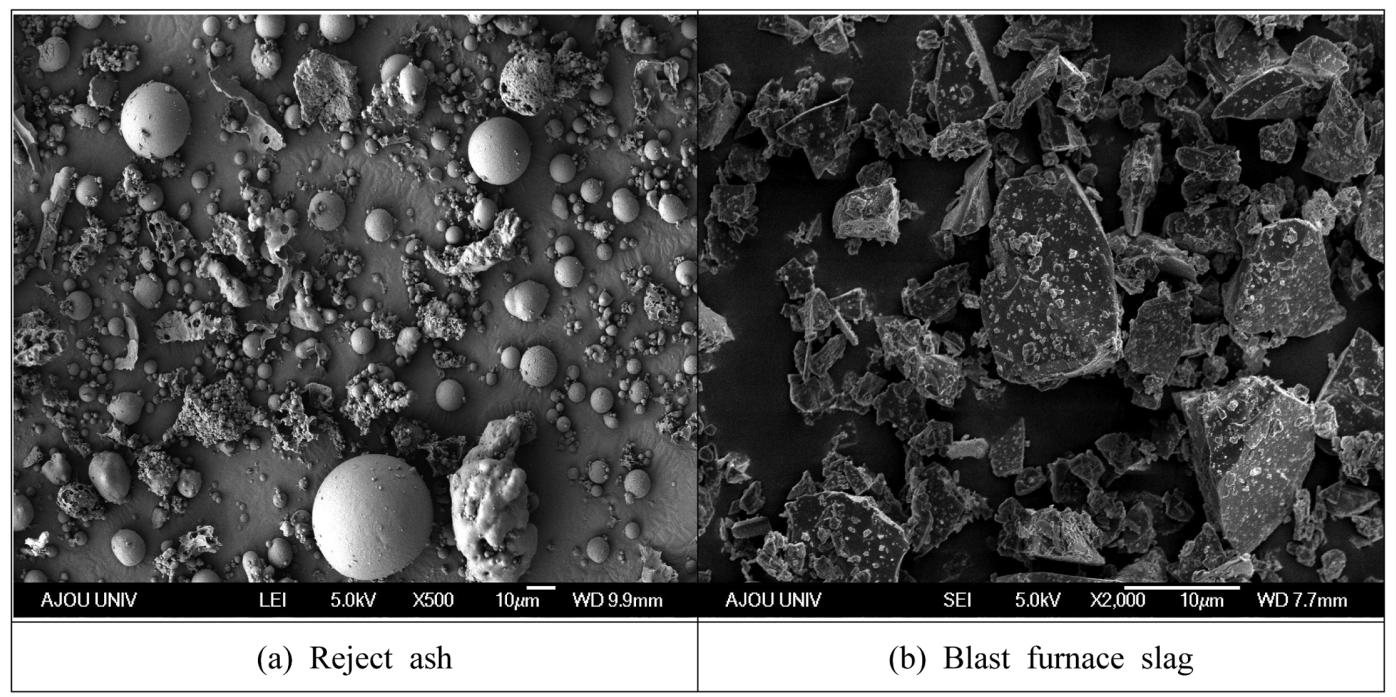

Fig. 1. Microstructure of the reject ash and blast furnace slag by SEM. 
같다. 입자의 형태를 비교하기 위하여 주사전자현미경 (Scanning Electron Microscope)으로 미세구조를 관찰하 였으며 그 결과를 Fig. 1에 도시하였다. 리젝트애쉬 미 세구조 관찰결과, $10 \mu \mathrm{m}$ 이하의 미립자와 $10 ~ 40 \mu \mathrm{m}$ 의 구형입자가 혼재하였고, 불규칙형상을 갖는 약한 응집입 자도 관찰되었다.

\subsection{2. 고로슬래그(Blast furnace slag)}

고로슬래그는 용광로에서 철을 생산할 때 생기는 부산 물로써 철을 제외한 부산물이다. 본 연구에서는 포항제 철소에서 발생하는 고로슬래그 미분말을 사용하였으며, 화학성분은 Table 1 과 같다. 고로슬래그 미분말은 산화 규소와 산화 알루미나의 함유량이 약 $50 \%$ 로 비교적 높 아 리젝트애쉬와 같이 어느 정도 중합반응을 기대할 수 있을 뿐만 아니라 특히 산화칼슘 $(\mathrm{CaO})$ 성분이 $43.13 \%$ 로 풍부하여 일반 시멘트와 같이 수화반응도 기대할 수 있을 것으로 판단된다. Fig. 1(b)는 고로슬래그 미분말의 $\mathrm{SEM}$ 사진이다. 고로슬래그의 미세구조를 관찰한 결과, 약 $10 \mu \mathrm{m}$ 이하의 불규칙형상의 입자들이 존재하는 것을 볼 수 있었다.

\section{2. 배합비 및 실험방법}

본 연구에서는 리젝트애쉬와 고로슬래그 미분말의 혼 합비율을 $100: 0,50: 50,0: 100$ 으로 하였으며, 원료로 리젝트애쉬와 고로슬래그, 경화제로 물유리 $\left(\mathrm{Na}_{2} \mathrm{SiO}_{3}\right.$, Daejung) 3호, $\mathrm{NaOH}$ (순도 $97 \%$ 이상, Deajung)을 사용 하였다. 물을 사용하여 원료와 경화제 비율을 $100: 40$ 으 로 고정한 뒤 물유리, $\mathrm{NaOH}$ 함량을 변수로 실험을 진 행하였다. 실험방법은 5 리터의 전동혼합기에 물유리, $\mathrm{NaOH}$, 물로 구성된 배합수를 넣고 리젝트애쉬와 고로 슬래그 미분말을 배합 한 후 모르타르 압축강도 측정용 큐브몰드 $(50 \times 50 \times 50 \mathrm{~mm})$ 에 채워 넣었다. 시험편을 배 합조건에 따라 제작하여 상온에서 24시간 양생 후 몰드 에서 탈형하여 시편을 제작하였다. 이렇게 제조된 시편 의 물성을 평가하기 위하여 재령 $1,7,28$ 일 후 압축강 도를 측정하였다.

\section{3. 결과 및 고찰}

3.1. 리젝트애쉬와 고로슬래그 미분말의 혼합비율에 따 른 영향

물유리와 $\mathrm{NaOH}$, 물의 비율을 고정시킨 후 결합재의 혼합 비율에 따른 배합비를 Table 2에 나타내었으며, 상 온의 양생조건에서 알칼리 활성 모르터의 결합재로 리젝
Table 2

Mixture proportions of ratio of RA and BS

\begin{tabular}{|c|c|c|c|c|c|}
\hline \multirow{2}{*}{ Sample } & \multicolumn{5}{|c|}{ RA : BS Water glass (wt\%) $\mathrm{NaOH}(\mathrm{wt} \%)$ Water (wt $\%$ ) } \\
\hline & 100 & 40 & & & \\
\hline Raw-I & $100: 0$ & & & & \\
\hline Raw-II & $50: 50$ & 3 & 1 & 9 & \\
\hline RawIII & $0: 100$ & & & & \\
\hline
\end{tabular}

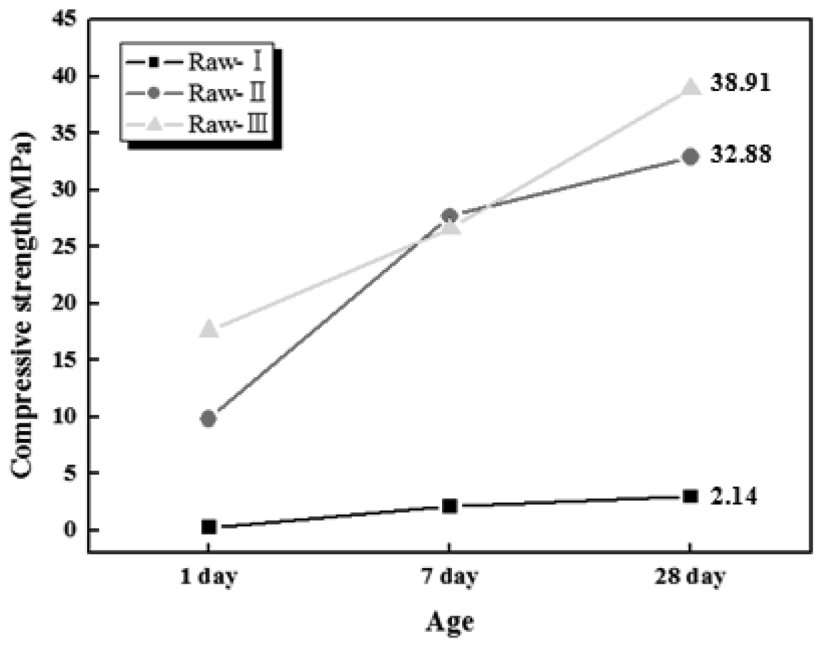

Fig. 2. Effect of the mixture ratio of reject ash (RA) and blast furnace slag (BS) on compressive strength. *Raw-I (RA100), *Raw-II (RA50Slag50), *Raw-III (Slag100).

트애쉬와 고로슬래그 미분말의 혼합비율이 압축강도에 미치는 영향을 분석한 결과를 Fig. 2에 나타내었다. Raw$\mathrm{I}(\mathrm{RA}: \mathrm{BS}=100: 0)$ 의 배합에서의 강도를 측정한 결과 재령 1 일차의 강도가 $0.28 \mathrm{MPa}$ 로 가장 낮은 강도를 발 현 하였는데 이는 상온조건에서 알칼리 활성화제로만은 리젝트애쉬의 축합중합 반응이 어렵다는 것을 의미한다. Raw-III(RA : BS = $0: 100)$ 의 배합에서 재령 1 일차 강도 가 $17.6 \mathrm{MPa}$ 로 가장 높았고 재령일이 증가할수록 높은 강도를 발현하여 28 일차 강도는 $38.91 \mathrm{MPa}$ 의 강도를 발 현하였다. 또한, Raw-II(RA : BS=50:50)의 배합에서 재령 1 일차에서는 강도가 $9.83 \mathrm{MPa}$ 로 비교적 낮으나 재 령일이 증가 할수록 높은 강도를 발현하여 재령 28 일차 강도는 고로슬래그 단독으로 사용한 Raw-III 조건보다는 낮지만 $32.88 \mathrm{MPa}$ 의 강도를 발현하였다. 이와 같이 리 젝트애쉬 단독으로는 강도발현이 어렵기 때문에 리젝트 애쉬 단독으로의 지오폴리머 중합반응을 활성화시키기 위해서는 여러 가지 방법이 있다. 예를 들어 고온양생을 실시하거나, 물리적으로 유리질 피막을 파괴시키는 방법, 본 연구와 같이 반응성이 강한 결합재와 혼합하여 사용 하는 방법이 있다. 본 연구의 결과와 같이 리젝트애쉬와 고로슬래그 미분말을 혼합한 모르터의 강도는 리젝트애 쉬 단독으로 사용하는 경우에 비해 강도가 향상되는 것 으로 나타났다. 이와 같이 알칼리 활성 모르터에서 고로 
슬래그 미분말과 리젝트애쉬를 혼합하여 사용한 경우 강 도 증진에 효과가 있는 것으로 판단된다. 이는 반응성이 강한 결합재인 고로슬래그가 강도에 영향을 미친 것으로 사료된다.

\section{2. $\mathrm{NaOH}$ 변화량에 따른 영향}

리젝트애쉬의 표면층은 유리질로 이루어져 있으며 유 리표면층이 조밀하고 화학적으로 안정한 상태를 가지고 있다. 이 표면층은 내부의 반응성이 높고 공극이 많은 구성 물질을 보호하는 역할을 하고 있다. 따라서 리젝트 애쉬는 자체적으로 지오폴리머 반응을 할 수 없기 때문 에 유리질 피막을 깨고 지오폴리머 반응에 관여하는 $\mathrm{Si}^{4+}, \mathrm{Al}^{3+}$ 이온을 용출시켜 반응을 일으킬 수 있는 강알 칼리 활성화제를 사용하는데 $\mathrm{OH}^{-}$의 농도가 높을수록 $\mathrm{SiO}_{2}-\mathrm{Al}_{2} \mathrm{O}_{3}$ 유리질 결합을 빨리 분해시키고 많은 양의 반응 이온들을 생성하게 된다. 따라서 알칼리 이온 농도 가 높으면 리젝트애쉬 활성화에 중요한 결정요소로서 알 칼리 자극제로 리젝트애쉬의 반응 물질 분해를 통해 높 은 강도 및 내구성을 가지는 지오폴리머 페이스트를 제 조할 수 있다. $\mathrm{NaOH}$ 변화량에 따른 배합비를 Table 3 에 나타내었다. 결합재는 $\mathrm{RA}: \mathrm{BS}=50: 50$ 으로 고정 시

Table 3

Mixture proportions of ratio of $\mathrm{NaOH}$

\begin{tabular}{llll}
\hline \multirow{2}{*}{ Sample } & RA : BS & $\mathrm{NaOH}(\mathrm{wt} \%)$ & Water (wt\%) \\
\cline { 2 - 4 } & 100 & 40 & \\
\hline $\mathrm{NaOH}-\mathrm{I}$ & & 0.1 & \\
$\mathrm{NaOH}-\mathrm{II}$ & $50: 50$ & 0.5 & 9 \\
$\mathrm{NaOH}-\mathrm{III}$ & & 1 & \\
$\mathrm{NaOH}-\mathrm{IV}$ & & 2 & \\
\hline
\end{tabular}

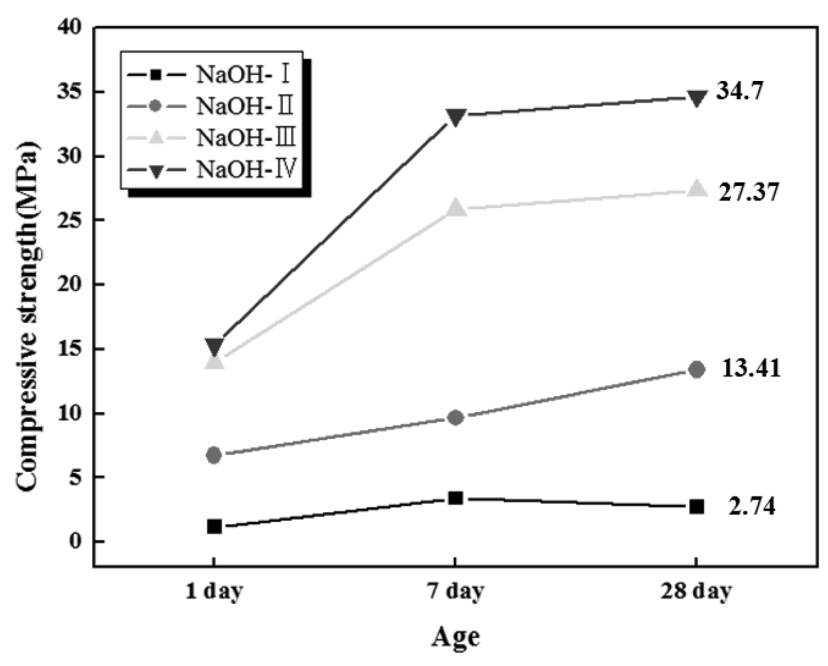

Fig. 3. Effect of the mixture ratio of $\mathrm{NaOH}$ on compressive strength. *NaOH-I (NaOH $0.1 \mathrm{wt} \%)$, *NaOH-II $(\mathrm{NaOH} 0.5$

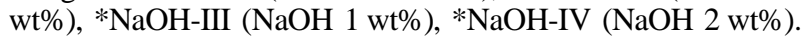

킨 뒤 $\mathrm{NaOH}$ 함량을 $0.1 \mathrm{wt} \%, 0.5 \mathrm{wt} \%, 1 \mathrm{wt} \%, 2 \mathrm{wt} \%$ 로 변화시켰다. Fig. 3에서 $\mathrm{NaOH}$ 알칼리 자극제의 함 량이 강도에 미치는 영향을 나타내었다. $\mathrm{NaOH}$ 의 함량 이 증가 할수록 강도가 증가하는 것으로 나타났으며 $\mathrm{NaOH}$ 의 함량이 $2 \mathrm{wt} \%$ 인 $\mathrm{NaOH}-\mathrm{IV}$ 의 28 일차 강도는 $34.7 \mathrm{MPa}$ 로 가장 높게 나타났다. 이것은 자극제의 농도 가 증가함으로써 결합재의 수화 및 중합반응을 촉진하였 기 때문으로 사료된다.

\section{3. 물유리 변화량에 따른 영향}

물유리의 혼합비는 지오폴리머를 제조 할 때 매우 중 요하다. 알칼리 활성화제로 $\mathrm{NaOH}, \mathrm{KOH}, \mathrm{Na}_{2} \mathrm{CO}_{3}$ 가 주 로 사용되는데 알칼리 활성화제로 물유리 $\left(\mathrm{Na}_{2} \mathrm{SiO}_{3}\right)$ 를 이 용하여 지오폴리머의 물성을 향상시킨다. 따라서 물유리 첨가량에 따라 지오폴리머에 미치는 영향을 검토하였다. Fig. 4는 물유리 변화량에 따른 강도그래프이다. Table 4 의 배합비와 같이 $\mathrm{RA}: \mathrm{BS}=50: 50, \mathrm{NaOH}$ 는 $1 \mathrm{wt} \%$ 로 고정시키고 물유리함량을 $0 \mathrm{wt} \%, 1 \mathrm{wt} \%, 3 \mathrm{wt} \%$ 그리고 $5 \mathrm{wt} \%$ 로 변화시켰다. 1 일차 강도에서는 물유리가 첨가 되지 않은 WG-I의 경우가 $14 \mathrm{MPa}$ 로 가장 높은 강도를 나타냈으며 물유리 첨가량이 $1 \mathrm{wt} \%$ 보다 $3 \mathrm{wt} \%$ 에서 강

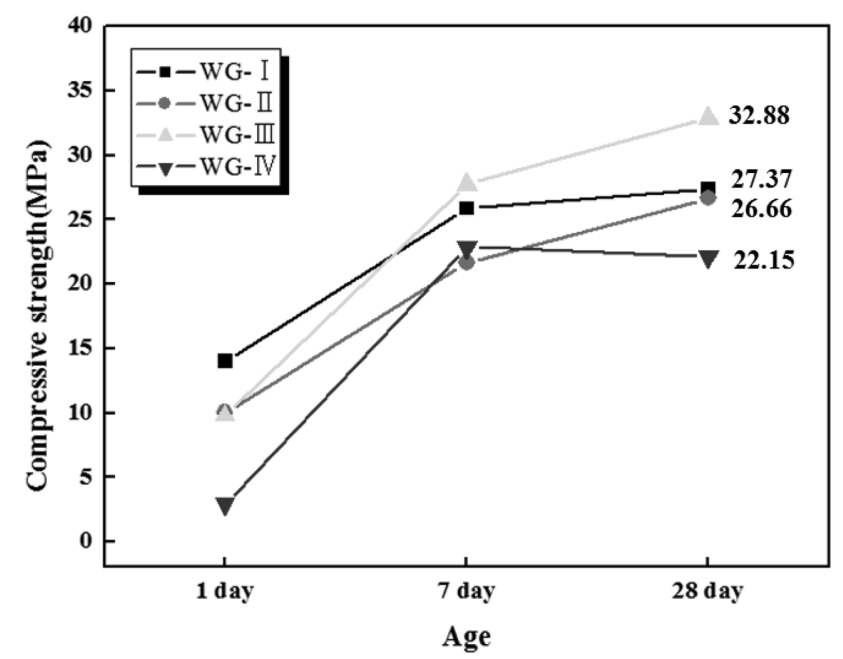

Fig. 4. Effect of the mixture ratio of water glass on compressive strength. *WG-I (Waterglass $0 \mathrm{wt} \%$ ), *WG-II (Waterglass 1 wt $\%$ ), *WG-III (Waterglass $3 \mathrm{wt} \%$ ), *WG-IV (Waterglass $5 \mathrm{wt} \%$ ).

Table 4

Mixture proportions of ratio of water glass

\begin{tabular}{|c|c|c|c|c|}
\hline \multirow{2}{*}{ Sample } & \multicolumn{4}{|c|}{ RA : BS Water glass (wt $\%) \mathrm{NaOH}(\mathrm{wt} \%)$ Water (wt $\%)$} \\
\hline & 100 & 40 & & \\
\hline WG-I & & 0 & & \\
\hline WG-II & $50 \cdot 50$ & 1 & 1 & 9 \\
\hline WG-III & $50: 50$ & 3 & 1 & \\
\hline WG-IV & & 5 & & \\
\hline
\end{tabular}




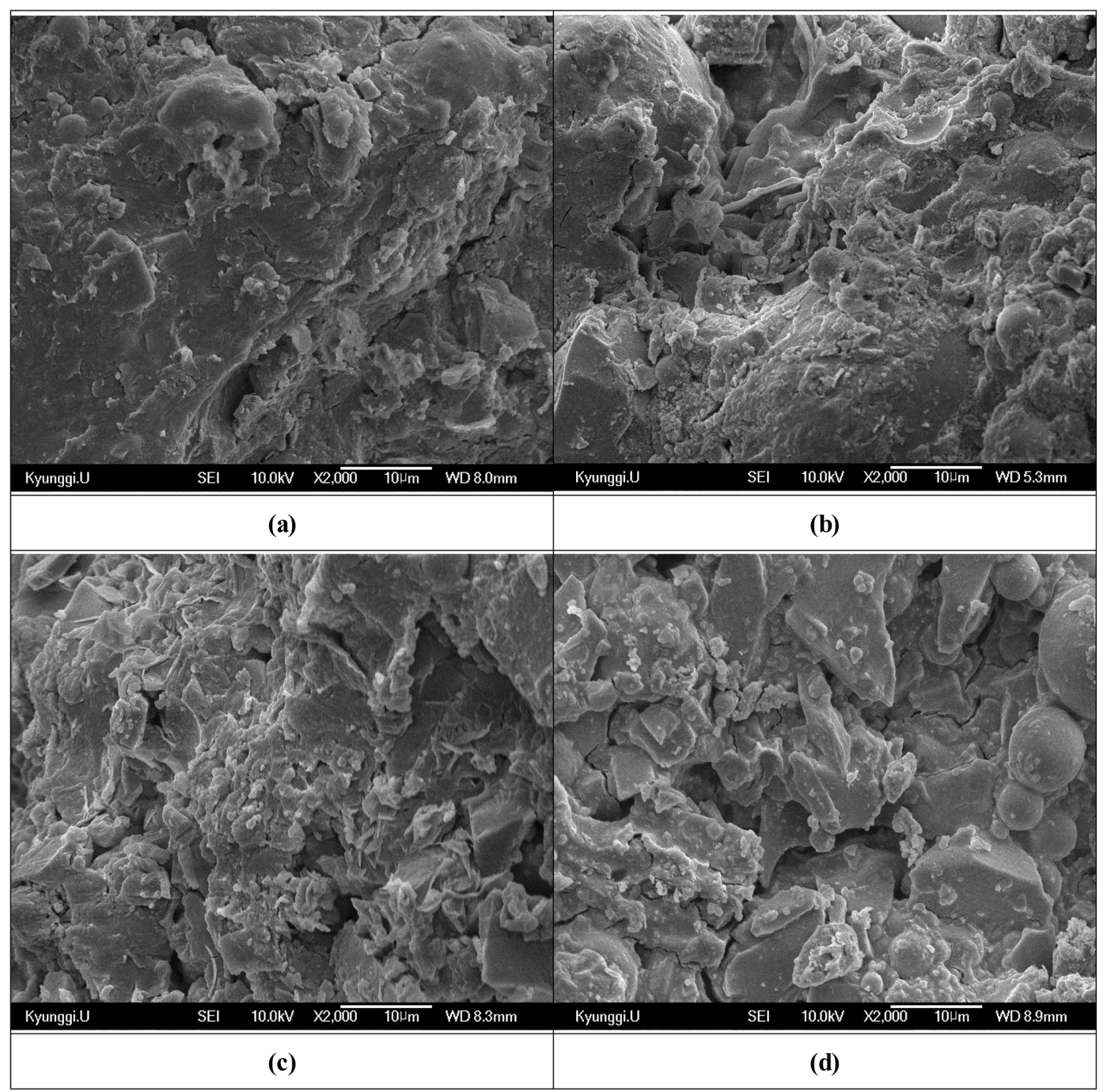

Fig. 5. FE-SEM micrographs of reject ash based geopolymers with the ratio of water glass (a) waterglass 0 wt $\%$, (b) waterglass $1 \mathrm{wt} \%$, (c) waterglass $3 \mathrm{wt} \%$ and (d) waterglass $5 \mathrm{wt} \%$.

도가 증가하여 28 일차 강도는 물유리 함량이 $3 \mathrm{wt} \%$ 인 WG-III의 경우가 일반적인 보통 포틀랜드 시멘트 모르 타르의 재령 28 일 강도인 약 $35 \mathrm{MPa}$ 에 근접하는 강도 값인 $32.88 \mathrm{MPa}$ 로 가장 높게 나타났으며 물유리를 첨가 하지 않은 경우와 $1 \mathrm{wt} \%$ 첨가한 경우가 WG-III의 경우 보다는 낮은 강도를 나타내었다. 또한 물유리 $5 \mathrm{wt} \%$ 를 첨가한 경우는 $22.15 \mathrm{MPa}$ 로 가장 낮은 강도를 발현하였 다. 물유리를 첨가한 후 물유리 첨가량에 따른 지오폴리 머의 미세구조를 Fig. 5에 나타내었다. Fig. 5(a) 및 (c) 의 미세구조 사진은 리젝트애쉬의 구형입자가 없는 치밀 하게 반응이 진행 된 모습을 보이고 있지만 Fig. 5(b) 및 (d)의 미세구조에서는 구형입자가 존재하는 모습을 보이고 있었다. 구형입자가 존재한다는 것은 경화제와 반응이 이루어지지 않은 결과로서 물유리가 가장 많이 들어간 Fig. 5(d)에서는 더욱 많은 구형입자가 존재하고 있고 낮은 강도를 나타내고 있으며 이는 물유리 함량이
증가할수록 지오폴리머 페이스트의 급결 현상이 발생되 므로 균열이 크게 형성되어 치밀성이 떨어지는 것으로 나타났다.

\section{4. 결 론}

본 연구에서는 결합재로 리젝트애쉬와 고로슬래그를 혼합하고 기본 활성화제로 $\mathrm{NaOH}$ 과 물유리를 사용하여 결합재 혼합비율과 알칼리 활성화제의 혼입에 따라 강도 발현에 미치는 영향을 검토한 결과 다음과 같은 결론을 얻었다.

1) 리젝트애쉬를 단독으로 사용할 경우에 비해 고로슬 래그 미분말과 리젝트애쉬를 혼합하여 사용한 경우 재령 일이 증가함에 따라 강도가 향상되는 것으로 나타났다.

2) 리젝트애쉬와 고로슬래그를 $50: 50$ 으로 고정하고 
$\mathrm{NaOH}$ 함량이 $2 \mathrm{wt} \%$ 일 때 재령 28 일차 강도는 34.7 $\mathrm{MPa}$ 로 가장 높게 나타났다.

3) 리젝트애쉬와 고로슬래그를 $50: 50$ 으로 고정하고 $\mathrm{NaOH} 1 \mathrm{wt} \%$, 물유리함량이 $3 \mathrm{wt} \%$ 인 시편에서 재령 28 일차 강도는 $32.88 \mathrm{MPa}$ 로 나타났다. 이는 미세구조에서 와 같이 다른 조성의 경우 구형의 리젝트애쉬가 그대로 존재했기 때문에 낮은 강도가 발현되었다.

\section{감사의}

본 연구는 2011학년도 경기대학교 학술연구비 지원에 의하여 수행되었습니다.

\section{참 고 문 헌}

[ 1 ] UNEP, "Kyoto protocol", UNEP Press (2002) p. 12.

[2] Q. Zhao, B. Nair, T. Rahimian and P. Balaguru, "Novel geopolymer based composites with enhanced ductility", J. Mater. Sci. 42 (2007) 3131.

[ 3 ] K. Komnitas and D. Zaharaki, "Geopolymerrisation; A review and prospects for the minerals industry", Miner. Eng. 20 (2007) 1261.

[4] L. Provis, C.Z. Yong, P. Duxson and J.S.J. Van Deventer, "Correlating mechanical and thermal properties of sodium silicate-fly ash geopolymer", J. Mater. Sci. 336 (2009) 57.

[ 5 ] D. Panias, I.P. Giannopoulou and T. Perraki, "Effect of synthesis parameters on the mechanical properties of fly ash-based geopolymers", Colloid Surf. A-physicochem. Eng. Asp. 301 (2007) 246.

[6] J.L. Bell, P.E. Driemeyer and W.M Kriven, "Formation of ceramics from metakaolin-based geopolymers: Part 1CS-based geopolymer", J. Am. Ceram. Soc. 92 (2008) 1.

[ 7 ] J. Davidovits, "Geopolymers and geopolymeric materials", J. Therm. Anal. 35 (1989) 429.

[ 8 ] J. Davidovits, "Inorganic polymeric new materials", J. Them. Anal. 37 (1991) 1633.

[ 9 ] W.K. Lee, S.G. Son, S.Y. Hong, J.H. Lee, E.Z. Park and Y.D. Kim, "Preparation and its characteristics of inorganic binder with MSWI bottom ash", J. Kor. Soc. Waste Mange. 25 (2008) 9.

[10] Z. Yunsheng, S. Wei, C. Qianli and C. Lin, "Synthesis and heavy metal immobilization behaviors of slag based geopolymer", J. Hazard. Mater. 143 (2006) 206.

[11] Sindhunata, "A conceptual model of geopolymerisation, $\mathrm{PhD}$ thesis", Department of Chemical and Biomolecular Engineering, The University of Melbourne (2006).

[12] P. Duxson, J.L. Provis, G.C. Lukey and J.S.J. van Deventer, "The role of inorganic polymer technology in the development of 'Green concrete", Cem. Concr. Res. 37 (2007) 1590.

[13] L. Choi and Y.J. Kwon, "Solving direction of the environmetal friendly policy in Korea cement industy". Magazine of the Korea Concrete Institute 18 (2006) 8.

[14] K.P. Lee, M.G. Hong, S.S. Lee and H.Y. Song, "Fundamental physical properties of cement composites containing fineness reject ash", J. Kor. Building Construction 11 (2011) 363.

[15] Y.T. Kim and Y.G. Ryu, "A study on the characteristics of ecological lightweight aggregates containing reject ash from the power plant", J. Kor. Crystal growth 20 (2010) 185. 